\title{
Novel gold(I) phosphine compounds inhibit HIV-1 enzymes
}

\author{
Pascaline Fonteh $^{a}$ and Debra Meyer*b \\ Received 6th May 2009, Accepted 28th July 2009 \\ First published as an Advance Article on the web 6th August 2009 \\ DOI: $10.1039 / b 909036 c$
}

\begin{abstract}
The increasing incidence of human immunodeficiency virus (HIV) infection and the associated acquired immune deficiency syndrome (AIDS) mortality rates as well as the sometimes severe side effects of highly active anti retroviral therapy (HAART) warrants the continuous search for new, less toxic drug candidates. The anti-HIV activity (inhibition of reverse transcriptase-RT and protease-PR in direct enzyme assays) of eleven gold(I) phosphine compounds are reported here. Uptake of the compounds by peripheral blood mononuclear cells (PBMCs) was demonstrated by inductively coupled plasma atomic emission spectroscopy (ICP-AES) while the effect of the compounds on cell viability was assessed using flow cytometry with annexin V and propidium iodide (PI). Of the 11 gold compounds tested, 7 significantly $(p<0.05)$ inhibited RT activity at concentrations of 25 and $250 \mu \mathrm{M}$ while 3 compounds significantly inhibited its activity at $6.25 \mu \mathrm{M}$. In the anti-protease assay, 4 of the compounds significantly inhibited the enzyme $(p<0.05)$ at $100 \mu \mathrm{M}$. All of the compounds were taken up by PBMCs (demonstrated by ICP-AES) and were non toxic to these cells at clinically tolerable concentrations. The potential of these novel gold(I) phosphine compounds as anti-HIV agents is therefore promising and worthy of further investigation.
\end{abstract}

\section{Introduction}

With more than 25 years elapsed since the discovery of HIV as the causative agent of AIDS, numerous investigators have dedicated enormous effort to finding promising drug leads (both synthetic and natural), to supplement existing treatment. ${ }^{1}$ A major success in the area of HIV/AIDS has been the use of HAART which has led to decreased morbidity and mortality. ${ }^{2}$ Drug resistance and the fact that treatment is not always well tolerated are some of the shortcomings of HAART e.g. the development of HIV strains resistant to AZT ( $3^{\prime}$-azido- $3^{\prime}$-deoxylthymidine); one of the first potent anti-RT drugs. Resistance to other drugs in addition to AZT and the side effects associated with HAART necessitates the development of novel potential drug leads for use in new cocktail formulations or as stand-alone agents. ${ }^{3}$

Gold-based drugs have a tremendous reputation in the treatment of many diseases e.g. rheumatoid arthritis with a resultant remission of the disease ${ }^{4}$ and have also been reported as having activity against microorganisms like HIV. In 1993, Okada and colleagues ${ }^{5}$ demonstrated the anti-HIV activity of aurothioglucose and aurothiomalate in cell-free and cell-based assays. These authors showed that inhibition of HIV by these compounds was through gold(I) ligand exchange of the reactive species bis(thiolato) gold(I) and acidic thiol groups exposed on viral surface proteins as well as by inhibition of reverse transcriptase in cell-free assays. Gold cyanide

\footnotetext{
${ }^{a}$ Biochemistry Department, University of Johannesburg, Auckland Park Kingsway Campus, P.O. Box 524 Auckland Park, 2006, Johannesburg, South Africa

${ }^{b}$ Biochemistry Department, University of Pretoria, Hatfield Campus, Pretoria 0002, South Africa.E-mail: debra.meyer@up.ac.za; Fax: + 2712362 5302; Tel: + 27124202300
}

$\left(\mathrm{Au}(\mathrm{CN})_{2}\right)$, a common metabolite in patients treated with gold-based drugs was also reported by Tepperman et al. ${ }^{6}$ (1994) to have anti-HIV activity through inhibition of reverse transcriptase. Other anti-arthritic agents e.g. auranofin led to an increase in the CD4 + count of an HIV positive patient being treated for psoriatic arthritis ${ }^{7}$ while aurothioglucose was further reported to inhibit HIV-1 replication in latently infected OM10.1 and Ach2 cells. ${ }^{8}$ In 2001, Yamaguchi et al. ${ }^{9}$ used a mouse AIDS model to show the in vivo anti-HIV activity of gold sodium thiomalate. More recently, Bowman et al. ${ }^{10}$ (2008) showed that the addition of gold nanoparticles to a failed HIV drug resulted in inhibition of viral entry into TZM-bl cells as well as decreased secretion of viral p24 antigens. Recent findings by our group demonstrated inhibition of both RT and PR by a gold(III) compound in direct enzyme inhibition assays. ${ }^{11}$ Gold-containing compounds therefore have potential as anti-HIV drugs and are worthy of further investigation.

Eleven novel gold(I) phosphine complexes and four of their ligands (starting material for producing gold-based drugs) were tested for potential inhibition of HIV enzymes. The use of phosphine gold compounds is supported by the fact that the presence of this group results in lipophilicity. Auranofin is an example of a phosphine-containing gold drug in clinical use which is taken orally notably because of its lipophilicity. ${ }^{12}$ Uptake of potential drugs into cells is very important for bioactivity; the injectable gold compound aurothioglucose (a non phosphine-containing complex) was shown to inhibit reverse transcriptase in cell free assays ${ }^{5}$ but together with its metabolites could not readily enter cells. Drug uptake is obviously important for effective inhibition of enzymes like $\mathrm{RT}$ in cell cultures and eventually in vivo. In general therefore, gold phosphine ligands are more lipophilic than 
non-phosphine analogues. Increases in lipophilicity enhance transport of the gold complex through cellular membranes and thus facilitate association of the gold compound with the intracellular active site. ${ }^{13}$ Earlier studies on structure activity relationships of 63 auranofin analogues demonstrated the importance of the phosphine ligand as derivatives lacking this moiety were significantly less active. ${ }^{14}$ The choice of gold(I) over gold(III) compounds for example avoids the toxicity that is associated with the oxidizing power of gold(III). ${ }^{15}$

The 11 novel gold(I) phosphine complexes and 4 ligands were tested in cell free anti-RT and anti-PR assays to determine their HIV therapeutic value. The uptake of the compounds by PBMCs was confirmed by ICP-AES while toxicity to these same cells was assessed using flow cytometry.

\section{Materials and methods}

\section{Compounds}

The compounds tested were provided by chemists from the Project AuTEK consortium (Mintek and Harmony Gold, South Africa). Material utilized in this study will be referred to as either gold compounds/complexes (meaning those that have a gold atom) or ligands (referring to compounds with no gold atom). All complexes are gold(I) phosphine compounds and only differ because of the different ligands used in their preparation. The synthesis, characterization and purity of all compounds (Fig. 1) except compound $\mathbf{1 0}$ (auranofin) were reported on previously. ${ }^{16-18}$ Compound $\mathbf{1 0}$ was purchased from Biomol International L.P. (Pennysylvania, USA). The compounds were dissolved in dimethyl sulfoxide (DMSO) and diluted in either assay buffer or culture media to a final DMSO concentration of $\leq 0.5 \%$ for experiments. The structures of the compounds and ligands as well as their molecular weights and designated numbers are shown in Fig. 1.

\section{HIV-1 reverse transcriptase assay}

The reverse transcriptase colorimetric assay kit from Roche Diagnostics (Mannheim, Germany) and recombinant HIV-1 RT (Merck Chemicals (Pty) Ltd Lab Supplies, South Africa) were used to test inhibition to RT. The enzyme $(20 \mu \mathrm{l}-0.2 \mathrm{U})$ was incubated with different concentrations of the gold compounds for $2 \mathrm{~h}$ and RT activity measured.

\section{Quantification of anti-PR activity of compounds}

This assay was performed according to procedures by Lam et al., ${ }^{19}$ using a fluorogenic substrate Arg-glu-(EDANS)Ser-Gln-Asn-Tyr-Pro-Ile-Val-Gln-Lys-(DABCYL)-Arg (Sigma, Missouri, USA) [where EDANS is 5-(2-aminoethylamino)-1naphthalene sulfonate and DABCYL is $4^{\prime}$-dimethylaminoazobenzene-4-carboxylate]. This substrate is a synthetic peptide sequence that contains a cleavage site (Tyr-Pro) for HIV-1 protease as well as two covalently modified amino acids for the detection of cleavage. ${ }^{20}$ An aliquot of the substrate $(16 \mu \mathrm{M}, 49 \mu \mathrm{l})$ and $1 \mu \mathrm{l}$ of HIV-1 PR solution $\left(1 \mu \mathrm{g} \mu \mathrm{l}^{-1}\right.$; Bachem, Switzerland) were added to a reaction mixture in assay buffer in the presence or absence (untreated control) of compounds to a final reaction volume of $100 \mu$ l. Following a $1 \mathrm{~h}$ incubation at $37^{\circ} \mathrm{C}$ in black 96 well assay plates (Corning
Incorporated, Corning, New York, USA), the fluorescence intensity was measured at an excitation wavelength of $355 \mathrm{~nm}$ and an emission wavelength of $460 \mathrm{~nm}$ using a Synergy microplate spectrofluorometer [BioTek, Analytical and Diagnostic Products (ADP), South Africa]. Acetyl pepstatin was used as a positive control for inhibition of HIV-1 protease while the blank consisted of assay buffer only. Data was analysed using the Gen $5^{\mathrm{TM}}$ software (ADP, South Africa) and the percentage inhibition calculated using the formula: $100-[($ Test reagent RFU/untreated control RFU) $\times 100)]$ where $\mathrm{RFU}=$ relative fluorescence units.

\section{Compound uptake using inductively coupled plasma atomic emission spectrometry (ICP-AES)}

Cell culture reagents were obtained from Highveld Biologicals (Sandringham, South Africa) unless stated otherwise. PBMCs were isolated by Ficoll gradient centrifugation and utilized in uptake and cytotoxicity assessment. Following isolation, PBMCs were resuspended in RPMI 1640 medium containing $2 \mathrm{mM}$ L-glutamine and supplemented with $10 \%$ foetal bovine serum and antibiotics $\left(10 \mathrm{mg} \mathrm{ml}^{-1}\right.$ penicillin $\mathrm{G}, 10 \mathrm{mg} \mathrm{ml}^{-1}$ streptomycin sulfate, $25 \mu \mathrm{g} \mathrm{ml}^{-1}$ fungizone and $1 \%$ gentamycin sulfate).

Some gold compounds have been shown to inhibit HIV in vitro in direct enzyme assays ${ }^{5}$ but were only minimally taken up by cells ${ }^{21}$ e.g. gold thioglucose. It was therefore necessary to determine the uptake of the gold complexes by PBMCs. This was done using ICP-AES: a fast multi-element technique that uses an ICP source to dissociate a sample into to its constituent atoms or ions exciting them to a wavelength characteristic of a particular element (gold in this case). This technique was successful in our experience for the confirmation of the uptake of other metals. ${ }^{22}$ The gold compounds were added to a final concentration of $25 \mu \mathrm{M}$ to $1 \times 10^{6}$ cells $\mathrm{ml}^{-1}$. The control wells contained cells and medium only. Following 7 days of incubation, the cells were washed twice with phosphate buffered saline (PBS) to remove non-absorbed material and treated with analytical grade nitric acid $(10 \%)$ and heat $\left(56{ }^{\circ} \mathrm{C}, 30\right.$ minutes). This process aids in disruption of proteins, lipids or any other macromolecules, which may interfere with the assay. Clarified cell lysates were analysed on a Liberty 110 ICP-AES spectrophotometer at $242.8 \mathrm{~nm}$. Absorption at this wavelength indicates the presence of gold in the lysate and the emission intensity is directly proportional to how much of a particular gold compound was taken up as compared to the control sample. A gold standard (Alfa Aesar, Ward Hill, USA) was used for calibrating the instrument and as a reference for gold based on the emission wavelength of the standard in relation to experimental treatments.

\section{Cell viability in the presence of gold compounds}

Flow cytometry, (using Annexin V and propidium iodide) was performed according to the manufacturer's instructions (Beckman Coulter, California, USA). Following 7 days of incubation $\left(5 \% \mathrm{CO}_{2}, 37{ }^{\circ} \mathrm{C}\right)$ of the gold compounds with PBMCs $\left(1 \times 10^{6}\right.$ cells ml $\left.{ }^{-1}\right)$, the cells were washed $(500 \times g$, 5 minutes) with ice cold PBS and transferred to plastic flow 
<smiles>CN(C)CCN=Cc1ccccc1-c1ccccc1-c1ccccc1</smiles>

3a $(\mathrm{Mr}=395.48) \quad 3 \mathbf{b}(\mathrm{Mr}=627.90) \quad$ 4a $(\mathrm{Mr}=362.45) \quad$ 4b $(\mathrm{Mr}=594.87)$

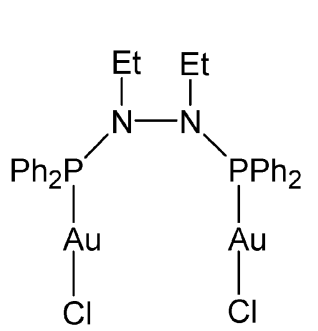

$5(\mathrm{Mr}=921.34)$<smiles>CCN1N(CC)N(CC)P(c2ccccc2)[Al](P(c2ccccc2)c2ccccc2)P(c2ccccc2)N1CC</smiles>

$6(\mathrm{Mr}=1145.42)$

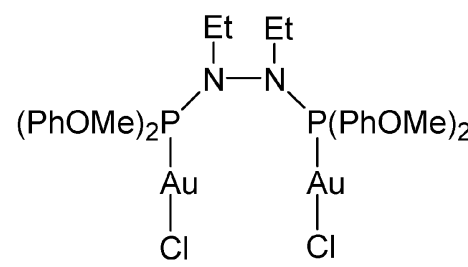

$7(\mathrm{Mr}=1045.47)$<smiles>CCN(P([Al]Cl)[Al]Cl)P([Al]Cl)N(C)C</smiles>

$8(\mathrm{Mr}=1109.74)$<smiles>CCOC(C)C(OC(C)=O)C(OC(C)=O)OC(C)=O</smiles>

$10(\mathrm{Mr}=678.49)$

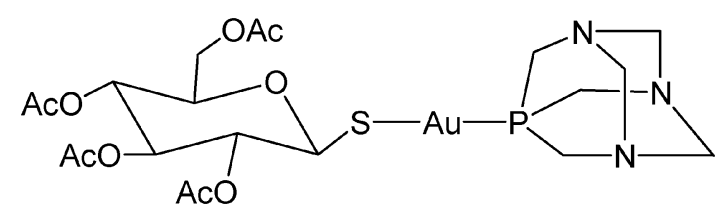

$9(\mathrm{Mr}=717.49)$

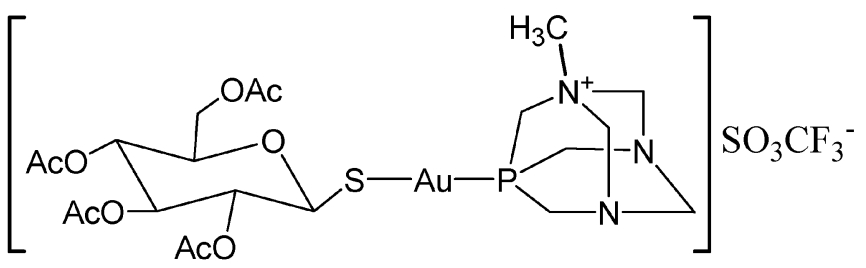

$11(\mathrm{Mr}=881.59)$

Fig. 1 Compounds assayed for anti-HIV-1 activity. 1a = (2-diphenylphosphanyl-benzylidene)-phenethyl, 1b = Benzyl-(2-diphenylphosphanylbenzylidene)-phenetyl-amine gold(I)chloride, $\mathbf{2 a}=N^{\prime}$-(2-diphenylphosphanyl-benzylidene)- $N, N$-dimethly-ethane-1,2-diamine, 2b $=N^{\prime}$-(2-diphenylphosphanyl-benzylidene)- $N, N$-dimethly-ethane-1,2-diamine gold(I) chloride, 3a $=$ 2-diphenylphosphanyl-benzyl)-phenethyl-amine, 3b $=$ 2-diphenylphosphanyl-benzyl)-phenethyl-amine gold(I) chloride, $4 \mathbf{a}=N^{\prime}$-(2-diphenylphosphanyl-benzyl)- $N, N$-dimethyl-ethane-1,2-diamine, $\mathbf{4 b}=N^{\prime}$-(2-diphenylphosphanyl-benzyl)- $N, N$-dimethyl-ethane-1,2-diamine gold chloride, $\mathbf{5}=$ Bis(diphenylphosphino)-1,2-diethylhydrazine di(gold chloride), $\mathbf{6}=$ Bis[bis(diphenylphosphino)-1,2-diethylhydrazine] gold chloride, $7=3$.7bis(di-(4-methoxyphenyl)phosphine)-1,2-dimethylhydrazine di(gold chloride) (6), $8=$ bis(di( $N, N$-dimethylaniline)phosphine)-1,2-dimethylhydrazine di(gold chloride) (4), $9=2,3,4,6$-tetra- $O$-acetyl-1-thio- $B$ D-glucopyranosato- $S$-)(1,3,5-triaza-7-phosphaadamantane) gold(I), $\mathbf{1 0}=(2,3,4,6$-tetra- $O$-acetyl-1-thio- $B$-D-glucopyranosato- $S$-)(triethylphosphine) gold(I), $\mathbf{1 1}=(2,3,4,6$-tetra- $O$-acetyl-1-thio- $B$-D-glucopyranosato- $S$ - $)(1,3,5$-triaza-7-phosphaadamantane $)$ gold(I) $(+1)$ trifluoromethanesulfonate $(-1)$. 1a, 2a, $\mathbf{3 a}$ and $\mathbf{4 a}$ are ligands for gold compounds $\mathbf{1 b}, \mathbf{2 b}, \mathbf{3 b}$ and $\mathbf{4 b}$ respectively. $\mathrm{Mr}=$ molecular weight. 
tubes (BD Biosciences, California, USA). The cell pellet was resuspended in $100 \mu \mathrm{l}$ of binding buffer followed by the addition of $1 \mu \mathrm{l}$ of annexin V-FITC solution and $5 \mu \mathrm{l}$ of propidium iodide working solution. After gentle mixing, the tubes were kept on ice in the dark for 15 minutes followed by the addition of $400 \mu \mathrm{l}$ of ice cold binding buffer. Controls included a solvent control $(0.5 \%$ DMSO $)$. The annexin positive, the PI positive as well as unstained cell controls were used for compensation and quadrant specification. The controls and samples suspended in $500 \mu \mathrm{l}$ of binding buffer were subjected to flow cytometric analysis with 10000 events collected for each sample within 30 minutes of treatment. Flow cytometric data for viability assessment was determined using a FACSCalibur (BD Biosciences, California, USA) and results processed using ProCellQuest ${ }^{\mathrm{TM}}$ software.

\section{Results}

The gold compounds inhibit reverse transcriptase activity

Of the 11 gold compounds tested, seven $(\mathbf{1 b}, \mathbf{2 b}, \mathbf{3 b}, \mathbf{4 b}, \mathbf{5}, \mathbf{7}$ and $\mathbf{8})$ significantly $(p<0.05)$ inhibited HIV-1 RT activity at concentrations of 25 and $250 \mu \mathrm{M}$. Three of the mentioned seven potential inhibitors $(\mathbf{4 b}, \mathbf{5}$ and 7$)$ also exhibited significant $(p<0.05)$ inhibition at $6.25 \mu \mathrm{M}$ (Fig. 2).

The inhibition of RT by all these compounds was greater than $50 \%$ and sometimes as high as $95.8 \%$. The ligands (1a, 2a, 3a, and 4a) and other gold compounds; 6, 9, 10 and 11 had no effect on the activity of HIV-1 RT. Percentages were calculated relative to an untreated control sample of enzyme and reaction mixture only. A positive inhibitor for HIV-1 RT (2.4 units inhibited RT 97.3\%) was used.

\section{Inhibition of protease activity}

Four of the complexes (4b, 6,9 and $\mathbf{1 1})$ significantly $(p<0.05)$ inhibited HIV-1 PR with more than $50 \%$ inhibition at $100 \mu \mathrm{M}$ (Fig. 3).

\section{Uptake of gold compounds by PBMCs}

All the gold compounds were taken up by PBMCs as shown in Table 1. Gold uptake by these cells was highest for compounds 4b and 8.

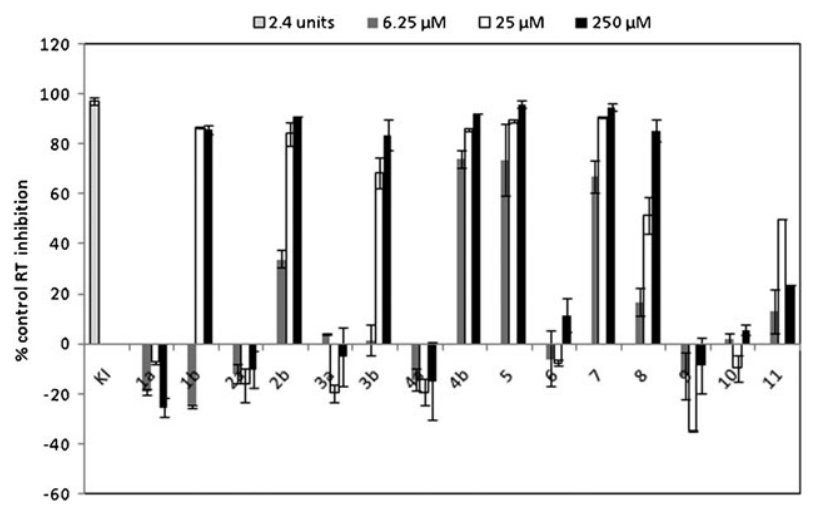

Fig. 2 The effect of gold compounds on reverse transcriptase. Gold complexes $\mathbf{1 b}, \mathbf{2 b}, \mathbf{3 b}, \mathbf{4 b}, \mathbf{5}, \mathbf{7}, \mathbf{8}$ significantly $(p<0.05)$ inhibited RT while 6, 9, 10 and 11 and the ligands (1a, 2a, 3a, and 4a) showed no inhibition of the enzyme. KI $=$ known inhibitor.

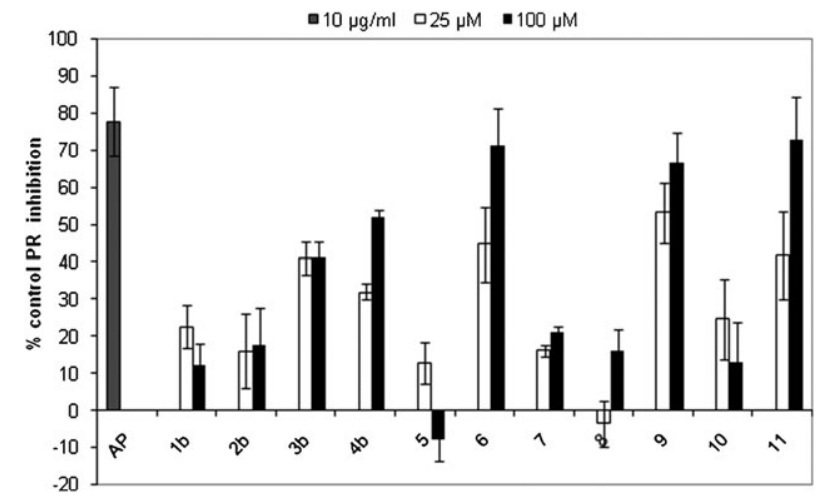

Fig. 3 The effect of gold compounds on protease. The gold complexes, fluorogenic substrate and HIV-1 enzyme were incubated at $37^{\circ} \mathrm{C}$ for $1 \mathrm{~h}$. The relative fluorescence unit (RFU) was obtained using a microplate reader at an excitation wavelength of $355 \mathrm{~nm}$ and emission of $460 \mathrm{~nm}$. Complexes $\mathbf{4 b}, \mathbf{6}, \mathbf{9}$, and $\mathbf{1 1}$ significantly inhibited HIV-1 PR with $>50 \%$ inhibition at $100 \mu \mathrm{M}$. AP $=$ acetyl pepstatin; a known protease inhibitor.

\section{Toxicity of compounds as measured by flow cytometry}

The tetrazolium dye 3-(4,5-dimethlythiazol-2-yl)-2-5-diphenyltetrazolium bromide (MTT) was initially used to assess potential cytotoxicity of the gold compounds, but because some of these compounds reduced and thus interfered with the dye, the flow cytometric assay was used instead. None of the compounds significantly reduced PBMC viability (Fig. 4).

\section{Discussion}

The shortcomings of HAART have led to the continual search for potential drug candidates for use as anti-HIV agents. Eleven gold(I) phosphine compounds and four ligands were tested to determine their inhibitory effect on HIV-1 enzymes: RT and PR. Seven of the gold compounds inhibited HIV-1 RT while four of them inhibited HIV-1 PR. Cross-inhibition was observed for $\mathbf{4 b}$, which inhibited both RT and PR. The compounds were taken up by PBMCs and were also non toxic to these cells.

Compound 10, which has been reported to have an inhibitory effect on HIV following an in vivo study where it was able to increase a patient's CD4 + count, ${ }^{7}$ did not however inhibit RT nor PR in vitro in this study. This suggests that $\mathbf{1 0}$ probably acts by a mechanism other than inhibition of the enzymes tested here. In a different study, incubation of compound $\mathbf{1 0}$ with cells reportedly led to a dose-dependent suppression in tumour necrosis factor mRNA induction. ${ }^{23}$ Tumour necrosis factor is regulated by $N F-\kappa B$ and this transcription factor regulates HIV-1 gene expression in latently infected cells. ${ }^{8}$ It is therefore possible that compound 10 inhibits HIV by suppressing these transcription factors and would not have inhibited RT and PR in the cell-free assays performed here. Another possible mechanism could be that $\mathbf{1 0}$ causes modification of a surface component of the virus as has been reported for other gold compounds that were shown to inhibit HIV. ${ }^{5}$ The RT inhibitory gold compounds may be better inhibitors of the enzyme because chlorine (attached to the $\mathrm{Au}$ - see structures in Fig. 1) makes a better leaving 
Table 1 The uptake of gold complexes by PBMCs. PBMCs were treated with gold compounds at $25 \mu \mathrm{M}$ and incubated for 7 days $\left(37{ }^{\circ} \mathrm{C}, 5 \% \mathrm{CO}_{2}\right)$. The cells were washed to remove excess compounds and lysed with $10 \%$ nitric acid. Clarified cell lysates were analysed for the presence of gold (an indication of the compound being taken up by the cells) using ICP-AES at $242.8 \mathrm{~nm}$. A gold standard (0-50 ppm) was used to establish the concentrations of the unknowns or treatments

\begin{tabular}{|c|c|c|c|}
\hline Gold compound & Concentration of gold taken up $/ \mu \mathrm{M}$ & Gold compound & Concentration of gold taken $u p / \mu \mathrm{M}$ \\
\hline $1 b$ & 0.42 & 7 & 0.3 \\
\hline $2 b$ & 0.51 & 8 & 4.91 \\
\hline $3 \mathbf{b}$ & 1.42 & 9 & 0.32 \\
\hline $4 b$ & 7.97 & 10 & 0.22 \\
\hline 5 & 0.09 & 11 & 1.61 \\
\hline 6 & 0.23 & & \\
\hline
\end{tabular}

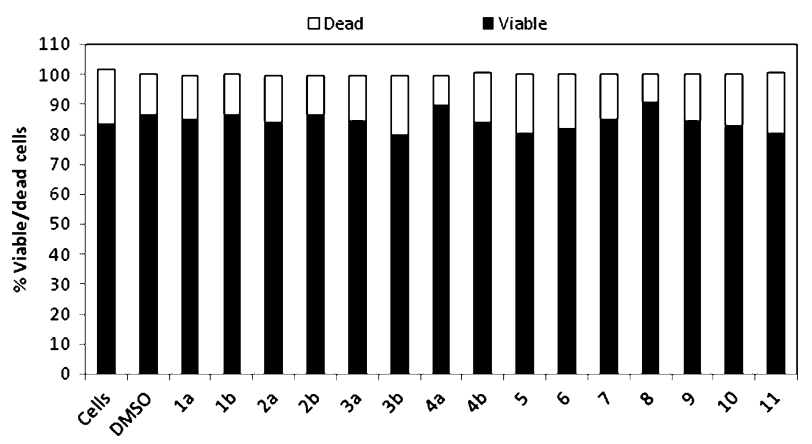

Fig. 4 The effect of gold compounds on the viability of PMBCs. PBMCs were incubated with the gold compounds $(25 \mu \mathrm{M})$ for 7 days at $37{ }^{\circ} \mathrm{C}$ under $5 \% \mathrm{CO}_{2}$. Cells treated with DMSO $(0.5 \%)$ and untreated cells were included as controls. Cell death was assessed using the annexin $\mathrm{V}$ antibody and propidium iodide.

group $^{13}$ than the tetraacetylthioglucose moiety of $\mathbf{1 0}$ and its analogues, i.e. 9 and 11, in ligand exchange reactions. Ligand exchange reactions are known to be one of the main mechanisms by which gold compounds inhibit RT and involves the gold binding to sulhydryl groups present on the surface of the enzyme. ${ }^{13}$ Thiol-ligand exchange reactions have been reported by various authors demonstrating the role of ligand exchange of gold compounds in different situations. ${ }^{12,13,24-26}$ Ligand exchange reactions with the complexes that have an easily accessible chlorine atom such as $\mathbf{1 b}, \mathbf{2 b}, \mathbf{3 b}, \mathbf{4 b}, \mathbf{5}, \mathbf{7}$ and $\mathbf{8}$ might therefore have been favoured as all these gold complexes inhibited RT. It is also possible that the gold compounds intercalate in the DNA molecule being formed in the reaction mixture of enzyme and nucleotides, thereby interfering with the reverse transcription reaction catalysed by RT. In our recent article, ${ }^{11}$ a gold(III) compound: tetrachloro[bis-(3,5-dimethylpyrazolyl)methane]gold(III) chloride, was shown to inhibit HIV-1 RT because of the dipyrazolium cation present in the structure. The presence of metals such as gold have been reported to aid in the enzyme inhibitory effect observed in metal-based drugs since metals play a key structural role in many enzymes. ${ }^{27}$ Other authors ${ }^{5,6}$ have also reported the inhibition of the RT enzyme by gold compounds in direct enzyme assays.

Enzymatic activity of HIV-1 PR was measured with a quenched fluorogenic substrate. ${ }^{20}$ This is an octapeptide comprised of a cleavage site linked to a fluorophore EDANS that is quenched by the $\mathrm{N}$-terminal DABCYL residue via intramolecular fluorescence resonance energy transfer (FRET). Four of the gold compounds $(\mathbf{4 b}, \mathbf{6}, \mathbf{9}, \mathbf{1 1})$ significantly $(p<0.05)$ inhibited HIV-1 PR at $100 \mu \mathrm{M}$ (Fig. 3). Chircorian and Barrios in $2004^{28}$ indicated a chrysotherapeutic effect of some compounds on lysosomal proteases which contain cysteine in their active site. It is tempting to speculate that the presence of such active sites at the dimerisation interface of HIV-1 PR resulted in their interaction with the gold in our compounds. The compounds that inhibited PR (i.e.4b, 6, 9 and 11) did not inhibit HIV-1 RT except $\mathbf{4 b}$ which inhibited RT at all three concentrations tested and minimally inhibited PR at $100 \mu \mathrm{M}$ (51.8\%, Fig. 3). Differences in compound structure might explain the different modes by which gold-based compounds inhibit either RT or PR. In Fonteh et al., a gold(III) compound is reported to inhibit both PR and $\mathrm{RT}^{11}$ and it was observed that inhibition of PR involved both the ligand and the auric acid moiety which served as starting material for gold in the synthesis of the compound. Differences in gold(I) and gold(III) compound structure might explain why only one of the gold(I) compounds inhibits both enzymes (with only marginal antiPR activity). On the other hand, differences in the inhibitory tendencies of the compounds could be attributed to the fact that gold is complexed to different ligands with different sizes which has a direct influence on the binding and thus biological activity of the compounds. Different ligands complexed to metals have been reported to result in varying activity. ${ }^{13,29}$ In our experience, the less bulky compounds (Fig. 1) appear to be more inhibitory, e.g. compound $\mathbf{4 b}$ is more inhibitory than 2b (diamine containing gold(I) phosphine compounds) and $5>7>8>6$ (diphosphine-containing compounds).

It was also generally observed that in both the RT and the PR assays, none of the ligands (1a, 2a, 3a and 4a) had inhibitory effects on the enzymes. Similar observations have been made by other authors ${ }^{28}$ who found that it was the presence of metallic gold in the complex and not the ligand that is necessary for therapeutic activity.

ICP-AES was previously used in our laboratory for determining uptake of metals by mononuclear cells ${ }^{22}$ and has been reported by McKeage et al. ${ }^{30}$ (2000) for the uptake of drugs and gold phosphine complexes. As mentioned before, gold thioglucose has been shown to inhibit HIV-1 RT in direct enzyme assays in vitro but could not be taken up by cells such that bioactivity assessment was impossible. ${ }^{21}$ All the gold compounds reported here were taken up by PBMCs at $25 \mu \mathrm{M}$ (Table 1). Since uptake was observed at the concentrations used in cytotoxicity, RT and PR inhibition testing, it is possible that inhibition of HIV in cell-based assays using our compounds is feasible. Compound $\mathbf{4 b}$ is shown to be taken up 
more efficiently by PBMCs (Table 1) and significantly inhibits RT at all three concentrations tested and PR at $100 \mu \mathrm{M}$. However compound $\mathbf{8}$ was efficiently taken up but did not significantly inhibit both enzymes except for RT at $250 \mu \mathrm{M}$. It would be interesting to correlate uptake and inhibition of HIV in cell-based antiviral assays for $\mathbf{4 b}$ and all the other gold compounds that inhibited either of the enzymes. The presence of the phosphine ligands in these gold compounds and the associated lipophilicity probably enhanced the uptake of the compounds. Studies on the extent of lipophilicity of each compound compared to the specific uptake per compound would better correlate this. Concentrations at which compounds were able to inhibit HIV-1 enzymes were also non-toxic to PBMCs according to flow cytometry and annexin V (Fig. 4). The ligands caused the least toxic effect on the cells compared to the gold compounds. All the gold compounds were tested 6 months after synthesis and were freshly prepared prior to activity screening. The possibility of the compounds losing biological activity over time and under different storage conditions form part of ongoing investigations.

\section{Conclusion}

All 11 novel gold(I) phosphine compounds reported here could be taken up by peripheral blood mononuclear cells and were non toxic to these cells. Seven of the gold compounds inhibited reverse transcriptase, while four displayed anti-protease, activity. The phosphine ligands assayed did not exhibit appreciable inhibition of either enzyme confirming the fact that the presence of the gold metal enhanced antiviral activity. Since uptake generally correlates to biological activity, these compounds show promise as potential inhibitors of these HIV-1 enzymes in cell culture and potentially in vivo and thus warrant further analysis.

\section{Acknowledgements}

We would like to thank Project AuTEK (Mintek and Harmony Gold) for financial support and access to study material. Additional funding was obtained from the Faculty of Science at the University of Johannesburg.

\section{References}

1 E. De Clercq, Towards improved anti-HIV chemotherapy: therapeutic strategies for intervention with HIV infections, J. Med. Chem., 1995, 38, 2491-2517.

2 F. J. Palella, K. M. Delaney, A. C. Moorman, M. O. Loveless, J. Fuhrer and G. A. Satten et al., Declining morbidity and mortality among patients with advance human immunodeficiency virus infection, N. Engl. J. Med., 1998, 338, 853-860.

3 E. J. Arts and M. A. Wainberg, Mechanisms of nucleoside analog antiviral activity and resistance during human immunodeficiency virus reverse transcription, Antimicrob. Agents Chemother., 1996, 40, 527-540.

4 S. L. De Wall, C. Painter, J. D. Stone, R. Bandaranayake, D. C. Wiley and T. J. Mitchison et al., Noble metals strip peptides from class II MHC proteins, Nat. Chem. Biol., 2006, 2(4), 197-201.

5 T. Okada, B. K. Patterson, S. Ye and M. E. Gurney, Aurothiolates inhibit HIV-1 infectivity by gold(I) ligand exchange with a component of the virion surface, Virology, 1993, 192, 631-642.
6 K. Tepperman, Y. Zhang, P. W. Roy, R. Floyd, Z. Zhao, J. G. Dorsey and R. C. Elder, Transport of the diacyanogold(I) anion, Met-Based. Drugs, 1994, 1(5-6), 433-443.

7 D. L. Shapiro and J. R. Masci, Treatment of HIV associated psoriatic arthritis with oral gold, J. Rheumatol., 1996, 23, $1818-1820$.

8 K. E. Traber, H. Okamoto, C. Kurono, M. Baba, C. Saliou, T. Soji, L. Parker and T. Okamoto, Anti-rheumatoid compound aurothioglucose inhibits tumour necrosis- $\alpha$ - induced HIV-1 replication in latently infected OM10.1 and Ach2 cells, Int. Immunol., 1999, 11(2), 143-150.

9 K. Yamaguchi, H. Ushijima, M. Hisano, Y. Inoue, T. Shimamura, T. Hirano and W. E. G. Muller, Immunodeficiency effect of gold sodium thiomalate on murine acquired immunodeficiency syndrome, Microbiol. Immunol., 2001, 45, 549-555.

10 M. Bowman, T. E. Ballard, C. J. Ackerson, D. L. Feldheim, D. M. Margolis and C. Melander, Inhibition of HIV fusion with multivalent gold nanoparticles, J. Am. Chem. Soc., 2008, 130, 6896-6897.

11 P. N. Fonteh, F. K. Keter, D. Meyer, I. L. Guzei and J. Darkwa, Tetra-chloro-(bis-(3,5-dimethylpyrazolyl)methane)gold(III) chloride: An HIV-1 reverse transcriptase and protease inhibitor, J. Inorg. Biochem., 2009, 103, 190-194.

12 C. F. Shaw III, A. A. Isab, J. D. Hoeschele, M. Starich, J. Locke, P. Schulteis and J. Xiao, Oxidation of the phosphine from the auranofin analogue, triisopropylphosphine (2,3,4,6-tetra- $O$-acetyl-1thio- $\beta$-D-glucopyranosato-S)gold(I), via a protein-bound phosphonium intermediate, J. Am. Chem. Soc., 1994, 116, 2254-2260.

13 H. S. Allaudeen, R. M. Snyder, M. H. Whitman and S. T. Crooke, Effects of coordinated gold compounds on in vitro and in situ DNA replication, Biochem. Pharmacol., 1985, 34, 3243-3250 and references therein.

14 I. Ott, On the clinical chemistry of gold complexes as anticancer drugs, Coord. Chem. Rev., 2009, 253, 1670-1681 and references therein.

15 R. V. Parish and S. M. Cottrill, Medicinal gold compounds, Gold Bulletin, 1987, 20(1/2), 3-11.

16 D. B. G. Williams, T. Traut, F. H. Kriel and W. E. van Zyl, Bidentate amino- and iminophosphine ligands in mono- and dinuclear gold(I) complexes: Synthesis, structures and $\mathrm{AuCl}$ displacement by AuC6F5, Inorg. Chem. Commun., 2007, 10, 538-542.

17 F. H. Kriel, M. Layh, J. Coates and H. M. Marques, Gold and silver complexes of bis(phosphino)hydrazine ligands as potential anti-tumour agents, August 2007, PhD Thesis, University of the Witwatersrand.

18 Z. Sam, in "Biomedical applications of gold: Stage 9", Mintek Communication C4050M, July 2005.

19 T. L. Lam, M. L. Lam, T. K. Au, D. T. M. Ip, T. B. Ng and W. P. Fong et al., A comparison of human immunodeficiency virus type- 1 protease inhibition activities by the aqueous and methanol extracts of Chinese medicinal herbs, Life Sci., 2000, 67, 2889-2896.

20 E. D. Matayoshi, G. T. Wang, G. A. Kraft and J. Erickson, Novel fluorogenic substrates for assaying retroviral proteases by resonance energy transfer, Science, 1990, 247, 954-958.

21 Y. Zhang, E. V. Hess, K. G. Pryhuber, J. G. Dorsey, K. Tepperman and R. C. Elder, Gold binding sites in red blood cells, Inorg. Chim. Acta, 1995, 229, 271-280.

$22 \mathrm{H}$. N. Traore and D. Meyer, Comparing qualitative and quantitative spectroscopic techniques for the detection of direct iron loading of mammalian cell cultures, Methods Cell Sci., 2001, 23, $175-184$.

23 K. I. Jeon, J. Y. Jeong and D. M. Jue, Thiol-reactive metal compounds inhibit NF- $\kappa \mathrm{B}$ activation by blocking I $\mathrm{B}$ kinase, J. Immunol., 2000, 164, 5981-5989.

24 M. T. Coffer, C. F. Shaw III, A. L. Horman, C. K. Mirabelli and S. T. Crooke, Thiol competition for $\mathrm{Et}_{3} \mathrm{PAuS}$-albumin: a nonenzymatic mechanism for $\mathrm{Et}_{3} \mathrm{PO}$ formation, J. Inorg. Biochem., 1987, 30, 177-187.

25 J. R. Roberts, J. Xiao, B. Schliesman, D. J. Parsons and C. F. Shaw III, Kinetics and mechanism of the reaction between serum albumin and auranofin (and its isopropyl analogue) in vitro, Inorg. Chem., 1996, 35, 424-433.

26 K. P. Bhabak and G. Mugesh, A synthetic model for the inhibition of glutathione peroxidase by antiarthritic gold compounds, Inorg. Chem., 2009, 48, 2449-2455. 
27 A. Louie and T. Meade, Metal complexes as enzyme inhibitors, Chem. Rev., 1999, 99, 2711-2734.

28 A. Chircorian and A. M. Barrios, Inhibition of lysosomal cysteine proteases by chrysotherapeutic compounds: a possible mechanism for the antiarthritic activity of $\mathrm{Au}(\mathrm{I})$, Bioorg. Med. Chem. Lett., 2004, 14, 5113-5116.

29 V. Radulovic, A. Bacchi, G. Pelizzi, D. Sladic, I. Brceski and K. Andjelkovic, Synthesis, structure and antimicrobial activity of complexes of $\mathrm{Pt}(\mathrm{II}), \mathrm{Pd}(\mathrm{II})$, and $\mathrm{Ni}(\mathrm{II})$ with the condensation product of 2-(diphenylphosphin)benzaldehyde and semioxamazide, Monatsh. Chem., 2006, 137, 681-691.

30 M. J. McKeage, S. J. Brenners-Price, P. Galettis, R. J. Bowen, W. Brouwer, L. Ding, L. Zhuang and B. C. Baguley, Role of lipophilicity in determining cellular uptake and antitumour activity of gold phosphine complexes, Cancer Chemother. Pharmacol., 2000, 46, 343-350. 